\title{
NMR による脂質膜中の薬物の「運動」の解析 Mobility of Drugs in Lipid Membranes by NMR
}

\author{
吉井 範行 \\ 姫路獨協大学 薬学部 \\ ₹ $670-8524$ \\ 兵庫県姫路市上大野 7-2-1 \\ Noriyuki YOSHII \\ Faculty of Pharmaceutical Sciences, Himeji \\ Dokkyo University, 7-2-1, Kamiohno, \\ Himeji 670-8524 Japan
}
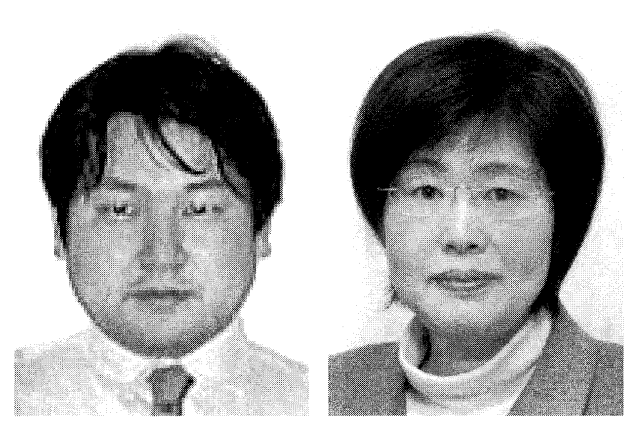

\author{
岡村 恵美子 \\ 姫路獨協大学 薬学部 \\ 于 670-8524 \\ 兵庫県姫路市上大野 7-2-1
}

Emiko OKAMURA

Faculty of Pharmaceutical Sciences, Himeji

Dokkyo University, 7-2-1, Kamiohno,

Himeji 670-8524 Japan

論文要旨：生体膜を構成する分子や膜のなかの薬物の「運動性」は, 薬物の膜輸送機構を明らかにするた めの重要な知見となる。膜は生理的条件下で常に摇らいでおり, 膜のなかの薬物の運動を多かれ少なかれ支 配している。筆者らは, 高分解能溶液 NMR とパルス磁場勾配（PFG）法を組み合わせて, 膜中の薬物や脂 質分子の運動をin situで観測し，定量化する方法を独自に開発した。生体膜モデルとして卵黄レシチンの 一枚膜ベシクル（large unilamellar vesicle, LUV; 直径 $100 \mathrm{~nm}$ ）を用いて，膜のなかの薬物の拡散運動や 膜への結合と解離のキネティクス，膜への結合量を明らかにした。また，通常の一次元 NMR 測定と PFG NMR 測定を使い分けることにより，さまざまな速さの結合・解離運動の測定が可能となることを見出した。 なお，ここではモデル薬物として5-フルオロウラシルとフッ素化ビスフェノール A を用いた。

Abstract: Mobility of drugs and biomembrane constituents is a key to elucidate the membrane transport mechanism in the cell. Lipid bilayer membrane is a dynamic structure where molecules are always fluctuating under physiological conditions. The mechanism of drug transport is related to the molecular dynamics in such soft, fluid membrane interface. To gain insight into molecular movements in membranes, we develop a noninvasive method to monitor dynamic properties of drugs and lipid components in membranes by applying multinuclear high-resolution solution NMR in combination with the pulsed-field-gradient (PFG) technique. We have quantified the diffusivity, the kinetics of membrane binding, and the bound fraction of the drug in situ by using large unilamellar vesicles of egg phosphatidylcholine as model cell membranes. The combination of $1 \mathrm{D}$ and PFG NMR serves to quantify the kinetics of membrane binding where the bound and the free components are unable to distinguish because of the rapid exchange on the NMR timescale. A small-sized 5-fluorouracil and fluorinated bisphenol A are used as a model drug.

Key words: NMR, pulsed field gradient method, mobility, diffusion, kinetics of binding

\section{1 はじめに}

生体膜を構成するさまざまな分子や膜のなかの薬物の 「運動性」は，薬物の膜輸送機構を明らかにするために， そして膜輸送の制御を行うために重要な知見となる。分 子の動きは, さまざまな物理化学的方法を用いて知るこ とができ11，このうち NMRは，1）調べたい原子サイ 卜を選択的に識別することができる，2）ピコ秒から秒 レベルにおよぶ幅広い時間スケールの動的情報が得られ

連絡者：吉井範行

E-mail : yoshii@himeji-du.ac.jp
る，3）プローブなどの助けを借りることなく，試料を そのまます状態で（非破壊的に）測定することができる など，生きたままの分子の情報をそのまま取りだせる点 で，非常に魅力的である。一方，NMR 法は，これまで 感度の点で劣っていた。ところが最近の装置の格段の進 歩により，核種をエンリッチしなくとも，数十 $\mu \mathrm{M}$, 場 合によってはそれ以下の濃度の定量的な運動性の測定が 可能となるまでに感度が向上した。それにともない，他 の方法では識別することができないようなわずかな変化 をNMR で検知することが可能になってきた。このよう な状況のなかで, NMR を用いて膜のなかの分子のさま 
ざまな動きを探ろうという試みが, 盛んになりつつある。

\section{2 膜のなかの分子の運動と NMR}

膜の構造的なゆらぎや膜輸送などに関連した分子の動 きを理解するためには, 膜内における分子の並進拡散(側 方拡散）を観測するのがよい方法である。分子の並進拡 散は，パルス磁場勾配 NMR 法 ${ }^{2)}$ を用いて捉えることが できる。この方法自体は新しいものではなく，すでに 1960 年代に最初の測定が行われている。もっとも，己 れまでは, 溶液やミセル系における拡散過程が NMR 研 究の中心であり, 脂質二分子膜や細胞膜など, 異方的で 複雑な膜環境のなかにおける分子の拡散過程の解析は, もっぱら，蛍光プローブを用いた測定に頼らざるを得な かった。蛍光プローブ法は感度の高い方法であるが, 計 測されるのはあくまでもプローブで標識された分子の振 る舞いである。薬物などの膜輸送は, 脂質二分子膜の動 きにどの程度支配されるのか？ 脂質二分子膜内の分子 の動きは，場所によって（局所的に）どのように異なる のか？これらの疑問に答えるためには，膜のなかの特 定の分子の動きに注目するだけでは十分でなく，膜のな かの複数の分字市動きを同時に観測する必要がある。こ のような目的に最もふさわしい測定法として，パルス磁 場勾配 NMR 法が再び脚光を浴びている。本稿では，筆 者らの成果を中心として, NMRによる膜のダイナミク スと薬物の運動の研究の最前線を紹介したい。

\section{NMR による薬物の識別}

系に摂動を与えることなく，膜に結合した薬物とバル ク中にある薬物を同時に観測することは容易でない。従 来，系にプローブを導入するか，薬物にラベリングして 測定が行われてきた。筆者らは，これらの方法を用いる ことなく，膜に結合した（bound）薬物と free の薬物の 運動状態をin situで同時に計測するために，新たな 2 つの NMR 測定手法を開発した。一つは, 高分解能溶液 NMR 測定とパルス磁場勾配スピンエコー（PFG）法を 組み合わせるものであり，もう一つは，膜脂質分子の濃 度を広範囲に変化させて, 一次元（1D）の高分解能溶 液 NMR 測定を行うというものである。高分解能溶液 NMR 法は，分子・原子レベルの構造・ダイナミクスに 関する情報を定量的に取得することができる優れた手法 である。分子の摇らぎや動きを何ら制限することなく， 自然のままの状態を捉えるこの方法の利点を活かして, 筆者らは, 固体 NMR ではなく「溶液 NMRによる膜研究」 を行っている。膜の自然な摇らぎと関係した薬物の運動 状態や輸送のプロセスをそのままの状態で観測するため

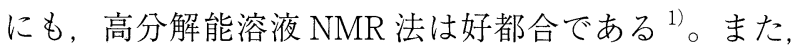

PFG 法は，分子の動的な性質の指標となる “拡散係数” を求める方法であり，これによって，分子の並進運動の 大きさを定量化することができる ${ }^{2)}$ 。したがって，高分 解能溶液 NMR と PFG 法を組み合わせることによって, 薬物や膜を構成する分子の運動や拡散過程を, in situで, それぞれ独立に捉えることが可能となる ${ }^{3)}$ 。PFG NMR 法, 高分解能の 1D NMR 法を適切に使い分けることに よって，膜のダイナミクスと薬物の運動をin situで定 量化することができるものと期待される。

\section{4 膜のなかの薬物の拡散}

膜のなかで薬物はどのように拡散していくのであろう か。膜のなかの拡散は，水中とどのように異なるのであ ろうか。筆者らは，抗がん剂として広く用いられている 5-フルオロウラシル (5FU, Fig. 1 (a))，および内分泌 かく乱物質ビスフェノール A のフッ素置換体 F- ビス フェノール A (FBPA, Fig. 1（b)）をモデル薬物に採 用して, NMR による膜のなかの薬物の拡散の解析を試 みた。その結果, NMR と PFG 法を組み合わせること により，膜に結合した薬物と free の薬物をin situで同 時に定量し, 薬物の結合量や膜のなかの拡散運動を明ら かにすることができた ${ }^{4)}$ 。ここでは，生体膜のモデルと して, 卵黄レシチン (EPC) の一枚膜ベシクル（LUV, 直径 $100 \mathrm{~nm}$ ）を用い，測定温度は，膜が液晶状態にあ る293〜313 K とした。いずれの薬物もフッ素原子を含 むため, ${ }^{19} \mathrm{~F}$ NMR を多用した。

最初に, $5 \mathrm{FU}$ の水溶液（濃度 2〜 $30 \mathrm{mM}$ ）にベシクル (EPC 濃度 40〜 $50 \mathrm{mM}$ ）を加え，NMR 計測を行った ${ }^{4)}$ 。 Fig. 2 にFUの $1 \mathrm{D}{ }^{19} \mathrm{~F}$ NMR スペクトルを示す。水溶 液中の $5 \mathrm{FU}$ のシグナルは，シャープな doubletとして 観測される (破線)。5FUの 5 位の $\mathrm{F}$ と 6 位の $\mathrm{H}$ 核間 の J-coupling によるためである。一方，ベシクルが存在 すると，Fig. 2 の実線のように，先に述べた doubletに 加えて，新しくブロードな成分（図中の*）が現れる。 新しく観測される成分（*) は，膜に結合した $5 \mathrm{FU}$ あると予想される。シグナルの帰属を確かめるために,<smiles>O=c1[nH]cc(F)c(=O)[nH]1</smiles>

a<smiles>Oc1ccc(C(c2ccc(O)cc2)(C(F)(F)F)C(F)(F)F)cc1</smiles>

b
Fig. 1 Molecular structure of 5-fluorouracil (5FU) (a) and fluorinated bisphenol A (FBPA) (b). 


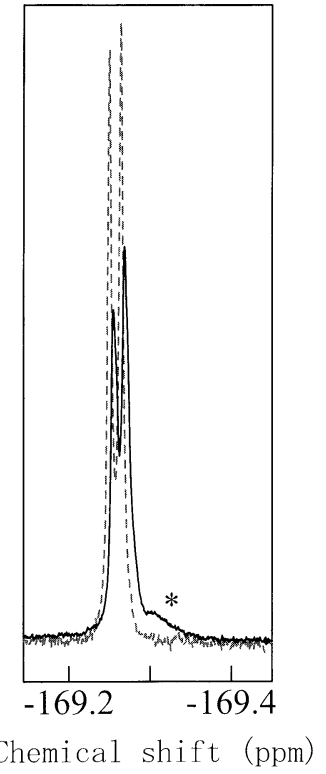

Fig. $21 \mathrm{D}{ }^{19} \mathrm{~F}$ NMR spectra of $3 \mathrm{mM} 5 \mathrm{FU}$ in the presence (solid line) and absence (dashed line) of EPC $\mathrm{LUV}^{4)}$. Asterisk shows a new peak that appears in the presence of the membrane.

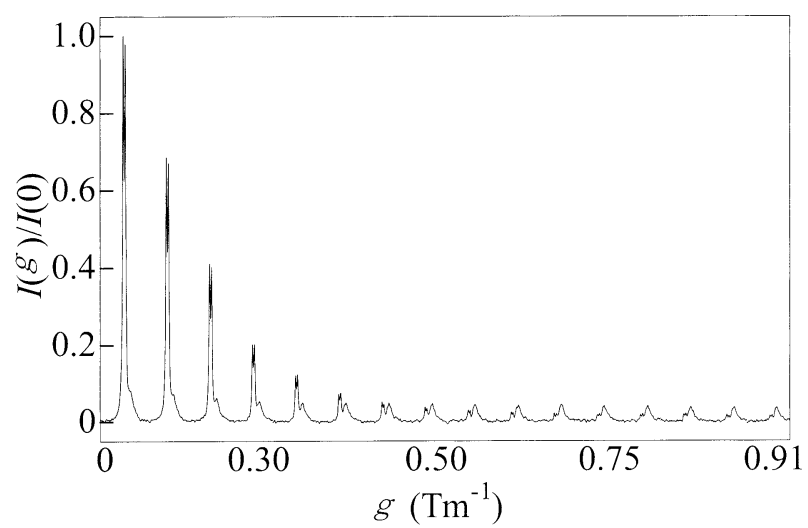

Fig. 3 Attenuation of ${ }^{19} \mathrm{~F}$ NMR signals of $2 \mathrm{mM} 5 \mathrm{FU}$ in the presence of LUV under the magnetic FG $(\mathrm{g})$ of $0.05,0.15,0.225,0.30,0.35,0.40,0.45,0.50,0.55,0.60$, $0.65,0.70,0.75,0.80,0.85$, and $0.91 \mathrm{~T} / \mathrm{m}$ (from left to right $)^{4)}$. Here the rectangular FG pulses were applied with a time interval $\left(\Delta_{\text {diff }}\right)$ of $100 \mathrm{~ms}$, with the gradient pulse width $(\delta)$ of $2 \mathrm{~ms}$.

PFG 測定を行った。膜に結合した $5 \mathrm{FU}$ は膜中で運動が 制限されるために PFG シグナルの減衰は遅い。一方, free の 5FUは運動が束縛されないために, バルク中で 速く拡散する。このために, PFG シグナルは磁場勾配 強度の増加にともなって free の成分が優先的に減衰す るはずである。実際, $5 \mathrm{FU}$ の $\mathrm{PFG}{ }^{19} \mathrm{~F}$ NMR シグナルは, Fig. 3 に示すように, 磁場勾配強度 $g$ が増加するに伴っ てシャープな doublet が急激に減衰し，ブロードな成分 が残った。 ${ }^{1} \mathrm{H}$ NMRに拈いても同様であった。このこと から 1D NMR スペクトル（Fig. 2）において新たに出現
したブロードな成分が膜に結合した $5 \mathrm{FU}$, doublet が freeの 5FUであることが確認された ${ }^{4)}$ 。

このように，運動性の違いを利用して，膜に結合した $5 \mathrm{FU}$ と free の $5 \mathrm{FU}$ を識別することができた。そこで, PFG NMR 測定から得られたシグナル強度 $I$ に対して, Stejskal-Tanner の関係式 ${ }^{5\rangle}$

$$
\ln \frac{I(g)}{I(0)}=-D m^{2}\left(\Delta_{\text {diff }}-\frac{\delta}{3}\right)
$$

を用いて, 膜に結合した $5 \mathrm{FU}$, free の $5 \mathrm{FU}$ の拡散係数 をそれぞれ算出した。ここで， $g$ は磁場勾配強度，Dは 拡散係数, $\Delta_{\text {diff }}$ は拡散時間, $m=\delta \gamma g$ であり, $\gamma$ は核磁気 回転比， $\delta$ はパルス幅である。膜に結合した $5 \mathrm{FU} の$ 拡 散係数は $303 \mathrm{~K}$ において $0.1 \times 10^{-10} \mathrm{~m}^{2} / \mathrm{s}$ であり, free のときの值 $9.5 \times 10^{-10} \mathrm{~m}^{2} / \mathrm{s}$ に比べて 2 桁近く小さくなっ た。さらに, 膜に結合した $5 \mathrm{FU}$ の拡散係数は, PFG ${ }^{1} \mathrm{H}$ NMR 測定によって得られた膜脂質分子の拡散係数 (0.1 $\times 10^{-10} \mathrm{~m}^{2} / \mathrm{s}$ ) と同程度であった。このことから, 膜中 の $5 \mathrm{FU}$ が，膜分子の流動性に支配されつつ膜内を拡散 している様子が明らかとなった（Fig. 4)。一方，高温で は，5FUの運動状態は膜分子の運動に支配されず，脂 質分子より大きな拡散係数を示した ${ }^{4)}$ 。

次に, FBPAについて検討を行った。Fig. 5 にFBPA の $1 \mathrm{D}{ }^{19} \mathrm{~F}$ NMR スペクトルを示す。FBPA は疎水性が 強く, 水への溶解度が極端に低い。このため, NMRに

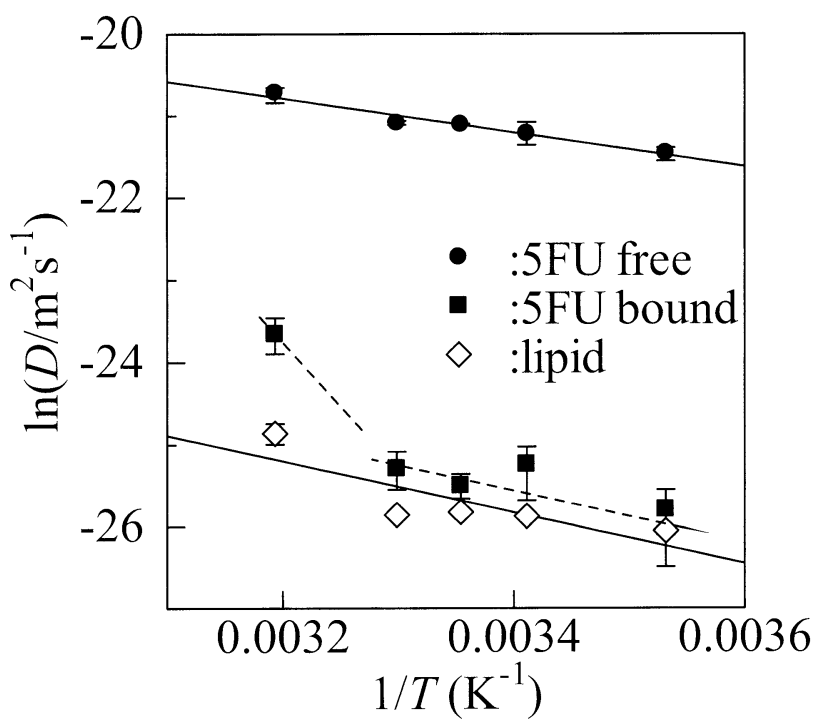

Fig. 4 Temperature dependence of the diffusion coefficients of membrane-bound and free 5FU, together with the mobility of the membrane lipid ${ }^{4)}$. Note that the dependence of the bound 5FU diffusion is deviated from the Arrhenius type at $313 \mathrm{~K}$. For free $5 \mathrm{FU}$ and the lipid, the temperature dependences of the diffusion are of the Arrhenius type with activation energies of 21 (free $5 \mathrm{FU}$ ) and $26 \mathrm{~kJ} / \mathrm{mol}$ (lipid), respectively. 


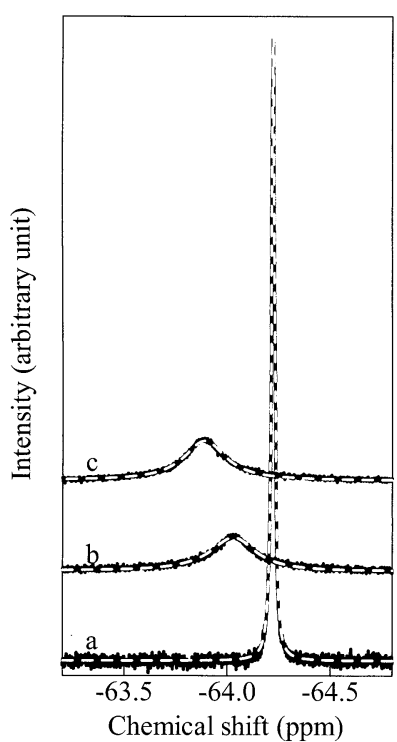

Fig. $51 \mathrm{D}{ }^{19} \mathrm{~F}$ NMR spectra of FBPA in the absence (a) and presence of 1 (b) and $40 \mathrm{mM}$ EPC LUV (c) at $303 \mathrm{~K}$. The solid lines show the observed spectra and the dashed lines are the fitting results of Eq. (4) to the respective NMR signals.

よるダイナミクスの定量解析は著しく困難であると考え られる。ここでは，溶媒である重水をFBPAに加えた 後 2 日間激しく攪拌して，FBPAの水溶液を調製した。 NMR でその濃度を定量したところ， $63 \mu \mathrm{M}$ であった。 これに，脂質濃度 0 から $40 \mathrm{mM}$ までのベシクルをそれ ぞれ加えた。FBPAはベンゼン環を 2 個含む構造であり， フッ素置換する前のビスフェノール A はオクタノール / 水分配係数の対数 $\log \mathrm{P}_{\mathrm{ow}}$ が 3.32 と大きな值を示すこ とから，膜への親和性が高い分子であると考えられる。 したがって，脂質濃度が高ければ，FBPAのほとんど すべてが膜中に分布すると考えてよい。実際，Fig. 6 に 示すように, FBPAの $1 \mathrm{D}{ }^{19} \mathrm{~F} \mathrm{NMR}$ シグナルは, 脂質 濃度の増加に伴ってピーク位置が-64.22 ppm から - $63.90 \mathrm{ppm}$ と低磁場側にシフトし, 濃度が $15 \mathrm{mM}$ を 超えるとピーク位置やシグナルの形状がほとんど変化し ないことを確認した。

そこで, 脂質濃度 $0,40 \mathrm{mM}$ のベシクル存在下で PFG NMR 測定を行い, free のFBPA，膜に結合した FBPAの拡散係数を決定した。その結果, freeの FBPA，膜に結合したFBPAの拡散係数は，それぞれ 5.2 $\times 10^{-10} \mathrm{~m}^{2} / \mathrm{s}$ および $0.075 \times 10^{-10} \mathrm{~m}^{2} / \mathrm{s}$ であった。膜に結 合したFBPAの拡散係数は, $5 \mathrm{FU}$ の場合と同様, free の場合に比べて 2 桁程度小さくなっていることがわかっ た。

溶液やミセル中と比較して二分子膜のなかの薬物の拡 散を NMR で観測することは極めてむずかしく,これまで モデル膜中での薬物の拡散挙動に関する研究は数例 $3,6,7)$

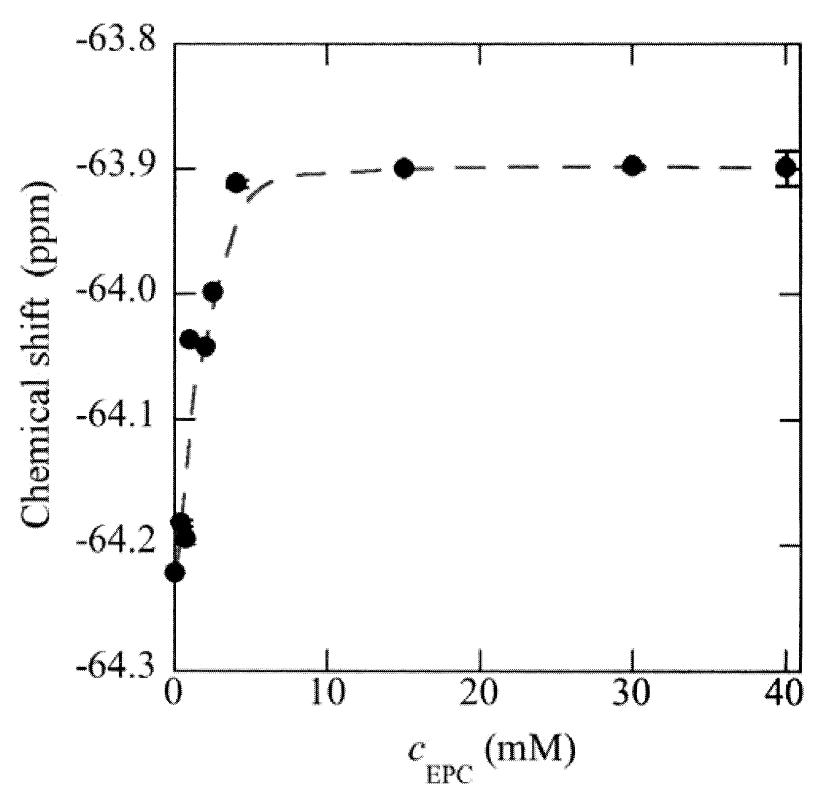

Fig. 6 Change in the chemical shift of FBPA ${ }^{19} \mathrm{~F}$ NMR signal as a function of the EPC concentration $c_{\mathrm{EPC}}$.

あるにすぎない。このようななかで，筆者らの開発した 方法を有効に活用して，今後，プローブや標識を用いる ことなく，低分子からぺプチド・タンパク質に至る膜の なかの薬物の拡散の “生の姿”が NMR で明らかにされ ることと思う。

\section{5 親水的な薬物と膜との結合・解離のキネティクス}

膜に対する薬物の結合と解離（Fig. 7）は，拡散とと もに，膜輸送を支配する重要なプロセスである。ところ が, バルクと膜との間での薬物の結合・解離に関する研 究は, 現在までほとんど行われていない。そこで, 筆者 らは, 上記 2 種の薬物の膜への結合, 解離について NMRによる研究を行い, 結合・解離速度をin situで定 量化することに成功した ${ }^{8)}$ 。

薬物の運動状態をin situで解析するために2つの NMR 測定手段があることは，すでに述べた。このうち， 親水性の $5 \mathrm{FU}$ に対しては, 高分解能溶液 NMR 測定と PFG 法を組み合わせた解析が有効である。なぜなら，4 で述べたように，膜に結合した（bound）成分と free の 成分は磁場勾配下で区別できるからである。そこで，こ こでは, 薬物の膜への結合・解離速度を明らかにするた めに, bound と freeの状態間の交換を考慮した Bloch 方程式の解析解 ${ }^{9)}$ による解析を行った ${ }^{8)}$ 。Bound およ び free の状態のシグナル強度 $I_{\mathrm{B}}$ および $I_{\mathrm{F}}$ はそれぞれ

$$
\begin{aligned}
I_{\mathrm{B}}(m)= & \left\{\frac{I_{\mathrm{B} 0}}{2}-\frac{\lambda I_{\mathrm{B} 0}-k_{\mathrm{FB}} I_{\mathrm{F} 0}}{2 \Delta}\right\} \exp \{(-\sigma+\Delta) \tau\}+ \\
& \left\{\frac{I_{\mathrm{B} 0}}{2}+\frac{\lambda I_{\mathrm{B} 0}-k_{\mathrm{FB}} I_{\mathrm{F} 0}}{2 \Delta}\right\} \exp \{(-\sigma-\Delta) \tau\}
\end{aligned}
$$




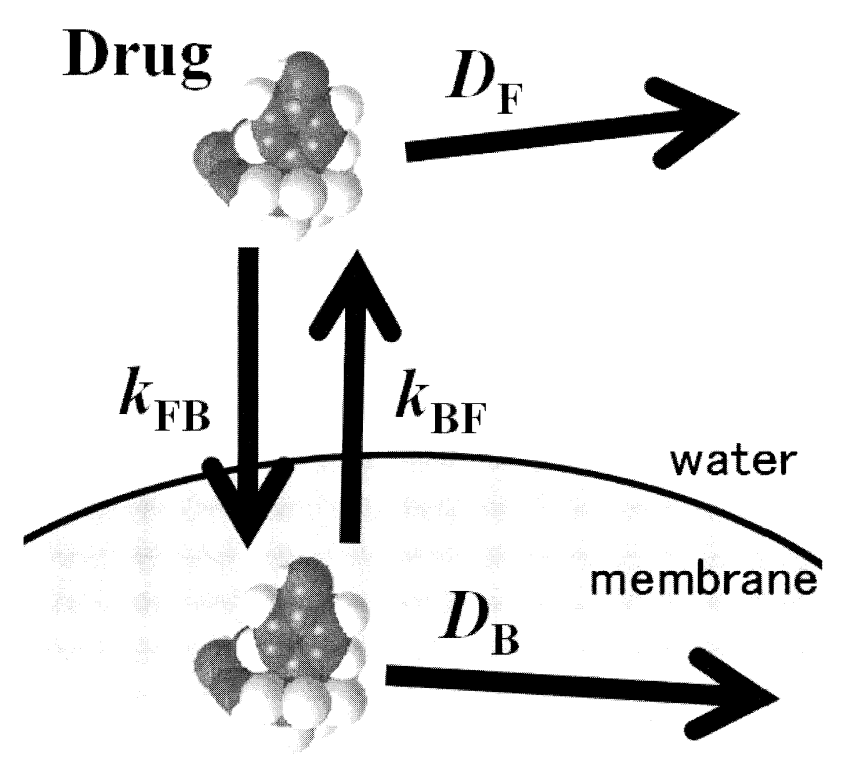

Fig. 7 Motion of drugs at the lipid membrane interface: diffusion and the exchange between the free and the bound states. Here $D_{\mathrm{F}}$ and $D_{\mathrm{B}}$ are the diffusion coefficients of drugs in bulk water and the membrane. $k_{\mathrm{FB}}$ and $k_{\mathrm{BF}}$ are the rate constants of binding and dissociation, respectively.

$$
\begin{aligned}
I_{\mathrm{F}}(m)= & \left\{\frac{I_{\mathrm{F} 0}}{2}+\frac{\lambda I_{\mathrm{F} 0}-k_{\mathrm{BF}} I_{\mathrm{B} 0}}{2 \Delta}\right\} \exp \{(-\sigma+\Delta) \tau\}+ \\
& \left\{\frac{I_{\mathrm{F} 0}}{2}-\frac{\lambda I_{\mathrm{F} 0}-k_{\mathrm{BF}} I_{\mathrm{B} 0}}{2 \Delta}\right\} \exp \{(-\sigma-\Delta) \tau\}
\end{aligned}
$$

である。ここで， $k_{\mathrm{FB}}, k_{\mathrm{BF}}$ は結合・解離の速度定数, $\sigma$ $=\left(k_{\mathrm{BF}}+k_{\mathrm{FB}}+D_{\mathrm{B}} m^{2}+D_{\mathrm{F}} m^{2}\right) / 2, \lambda=\left(k_{\mathrm{BF}}-k_{\mathrm{FB}}+D_{\mathrm{B}} m^{2}\right.$ $\left.-D_{\mathrm{F}} m^{2}\right) / 2, \tau=\Delta_{\text {diff }}-\delta / 3$ および $\Delta=\sqrt{\lambda^{2}+k_{\mathrm{BF}} k_{\mathrm{FB}}}$ である。 また $D_{\mathrm{B}}$ および $D_{\mathrm{F}}$ はそれぞれ bound および free の $5 \mathrm{FU}$ の拡散係数である。最初に，式（2）および（3）による 解析の妥当性を確かめるために, bound および free の 実測のシグナル強度に両式をフィッティングさせた。 $k_{\mathrm{FB}}$ と $k_{\mathrm{BF}}$ をフィッィング・パラメータとし, $D_{\mathrm{B}}$ と $D_{\mathrm{F}}$ は式（1）を用いて得られた值に固定した。結果は, Fig. 8 に示すように, 両式は, いずれの温度においても 実測值をよく再現した。

そこで, 式 (2)，（3）を用いて結合・解離の速度定 数 $k_{\mathrm{FB}}$ と $k_{\mathrm{BF}}$ を算出した。 $5 \mathrm{FU} の k_{\mathrm{FB}}, k_{\mathrm{BF}}$ は, 濃度 $10 \mathrm{mM}$ では, 脂質濃度 $40 \mathrm{mM}$ の膜に対して, $303 \mathrm{~K}$ で それぞれ 0.2 および $4.1 \mathrm{~s}^{-1}$ となった。したがって半減期

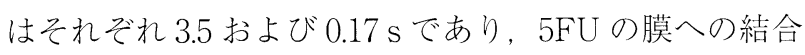
と解離は, NMR 測定の時定数 (サブ秒〜秒) と同程度 の slow exchangeであることがわかった。また， $k_{\mathrm{FB}}$ と $k_{\mathrm{BF}}$ の温度依存性から求めた活性化エネルギーは, $57 \mathrm{~kJ} / \mathrm{mol}$ であった。膜内での拡散運動については, Fig. 4 における $D_{\mathrm{B}}$ のアレニウスプロットから, 活性化

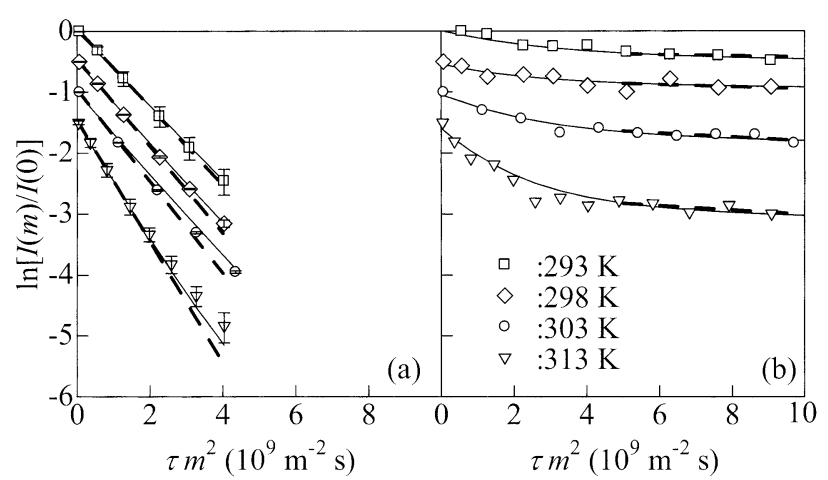

Fig. 8 Signal attenuation of (a) free and (b) bound components of $5 \mathrm{FU}$ at $293(\square), 298(\diamond), 303$ $(\bigcirc)$, and $313 \mathrm{~K}(\nabla)^{8)}$. The symbols represent the experimental values and the solid lines are obtained by fitting Eqs. (2) and (3) to the signal intensity. The results of $T=298,303$, and $313 \mathrm{~K}$ are shifted to negative value by $-0.5,-1.0$, and -1.5 , respectively. The symbols in (a) indicate the average of the doublet peak intensities, and the error bar represents the deviation of the observed intensity from the average value.

エネルギーが $26 \mathrm{~kJ} / \mathrm{mol}$ となることがわかっている ${ }^{4}$ 。 これらの比較から, $5 \mathrm{FU}$ の膜法線方向の運動は, 側方 拡散に比べて制限されていることが明らかとなった ${ }^{8)}$ 。

\section{6 疎水的な薬物と膜との結合 - 解離のキネティクス}

FBPAの 1D NMR スペクトル（Fig.5）では，いずれ の脂質濃度に拈いても bound と free のシグナルが分離 されず,一本になっている。このことから, FBPA は $5 \mathrm{FU}$ の場合と異なり, 高速で結合・解離を繰り返す fast exchange の状態にあることがわかる。シグナルは結合 および解離状態が平均化されているため, $5 \mathrm{FU} の$ 場合 のような PFG NMR 法による識別ができない。そこで, ここでは一次元の高分解能溶液 NMR シグナルを用い て, 以下の解析を試みた ${ }^{10)}$ 。速度定数 $k_{\mathrm{FB}}, k_{\mathrm{BF}}$ で bound と freeの 2 状態間を交換するFBPAに対する Bloch 方程式から導かれる1D NMR シグナル強度 $I(\omega)$ は

$$
\begin{aligned}
I(\omega) & =I_{\mathrm{B}}(\omega)+I_{\mathrm{F}}(\omega) \\
& =\frac{I_{0}}{\pi} \frac{\beta_{\mathrm{F}} f_{\mathrm{B}}+k_{\mathrm{FB}} f_{\mathrm{F}}+\beta_{\mathrm{B}} f_{\mathrm{F}}+k_{\mathrm{BF}} f_{\mathrm{B}}}{\beta_{\mathrm{B}} \beta_{\mathrm{F}}-k_{\mathrm{BF}} k_{\mathrm{FB}}}
\end{aligned}
$$

で表される。ここで $\omega$ は化学シフトに対応する振動数 であり， $I_{\mathrm{B}}$ と $I_{\mathrm{F}}$ は膜に結合した成分と free 成分のシグ ナル強度， $I_{\mathrm{B} 0}$ と $I_{\mathrm{F} 0}$ はそれぞれの純状態を表し $I_{0}=I_{\mathrm{B} 0}+$ $I_{\mathrm{F} 0}$ である。 $f_{\mathrm{j}}$ は状態 $j(=\mathrm{B}$ or F $)$ の分子の割合である。 また式（4）中の $\beta_{\mathrm{B}}$ および $\beta_{\mathrm{F}}$ は，

$$
\beta_{\mathrm{B}}=\frac{1}{T_{2 \mathrm{~B}}^{0}}+\frac{i \omega_{\mathrm{B}}^{0}}{2 \pi}+k_{\mathrm{BF}}-\frac{i \omega}{2 \pi} \text { および }
$$




$$
\beta_{\mathrm{F}}=\frac{1}{T_{2 \mathrm{~F}}^{0}}+\frac{i \omega_{\mathrm{F}}^{0}}{2 \pi}+k_{\mathrm{FB}}-\frac{i \omega}{2 \pi} \quad \text { (5) 式 }
$$

ただし， $T_{2 \mathrm{j}}^{0}$ と $\omega_{\mathrm{j}}^{0}$ は純状態 $j(=\mathrm{B}$ or $\mathrm{F})$ の横緩和時間 と共鳴振動数である。

FBPA は脂溶性が高く水に溶けにくいため, Fig. 6 か らも示唆される通り，高濃度べシクル溶液中では，ほほ すべてがベシクルに結合している。そこで式（5）の $T_{2 \mathrm{~B}}^{0}$ と $\omega_{\mathrm{B}}^{0}$ は, 高濃度ベシクル溶液 $\left(\mathrm{EPC}\right.$ の濃度 $c_{\mathrm{EPC}}=$ $40 \mathrm{mM})$ 中の FBPAのシグナルから, $T_{2 \mathrm{~F}}^{0}$ と $\omega_{\mathrm{F}}^{0}$ は $\mathrm{FBPA}$ 水溶液 $\left(c_{\mathrm{EPC}}=0 \mathrm{mM}\right)$ 中の FBPA のシグナルから, それぞれ求めた。

実測した1D スペクトルに式（4）をフィッティング した結果を, Fig. 5 に破線で示す。いずれの場合も式 (4) は実測のスペクトルを良く再現することがわかる。した がって，式（4），(5) を用いて1D スペクトルの解析を 行った結果, 温度が $303 \mathrm{~K}$ ではFBPAの $k_{\mathrm{FB}}$ と $k_{\mathrm{BF}}$ が $c_{\mathrm{EPC}}$ に応じて数十〜数百 $\mathrm{s}^{-1}$ の範囲で変化することがわ かった。対応する半減期はいずれもミリ秒のオーダーと なる。これは $5 \mathrm{FU} の$ 数十〜数百分の一程度であり, FBPA が非常に高速で膜とバルクの間を行き来してい る様子がうかがえる。

このように，薬物の膜との結合解離の時定数が NMR 測定に要する時間より長いか同程度の場合（slow exchange limit）には, PFG 法により結合および解離の 2 状態のシグナルを分離して解析し, また短い場合 (fast exchange limit）には，1D NMR 測定を行って 2 状態が 混合したシグナルを解析すればよい。これらを使い分け ることにより，さまざまな速さの結合解離運動の測定が 可能であることが明らかとなった。

\section{7 薬物の膜への結合量と膜内での熱力学的安定性}

薬物の膜への結合量 $f_{\mathrm{B}}$ は, 実測で得られた $k_{\mathrm{FB}}$ と $k_{\mathrm{BF}}$ から $f_{\mathrm{B}}=k_{\mathrm{FB}} /\left(k_{\mathrm{BF}}+k_{\mathrm{FB}}\right)$ により評価することができる。 そこで, 膜に対する $5 \mathrm{FU} と \mathrm{FBPA} の$ 結合量をin situ で定量した。温度 $303 \mathrm{~K}$ において，5FUは，濃度が2〜 $30 \mathrm{mM}$ の範囲で全体の約 10\%が膜に結合していた。一 方, FBPAは, 脂質の濃度 $(0 \sim 40 \mathrm{mM})$ に応じて結合 量が 0 〜 100\%の間で変化した。得られた結合量からバ ルクと膜中における自由エネルギー差 $\Delta G$ を評価する と, $5 \mathrm{FU}$ の場合 $\Delta G$ は $3 \mathrm{~kJ} / \mathrm{mol}$ であり， $303 \mathrm{~K}$ におけ る熱ゆらぎ $2.5 \mathrm{~kJ} / \mathrm{mol}$ と同程度であった ${ }^{4)}$ 。このことか ら，5FUは膜への結合がそれほど優位でないことがわ かる。この結果は, 筆者らが現在行っている分子動力学 シミュレーションによる計算結果とも一致する。一方, FBPAの $\Delta G$ は約 $20 \mathrm{~kJ} / \mathrm{mol}$ であり，膜との親和性が高 いことが明らかとなった ${ }^{10)}$ 。 $5 \mathrm{FU}$ は核酸塩基であるウ
ラシルの誘導体であり親水的であるのに対し, FBPA は分子内にベンゼン環を 2 つ有する疎水的な分子であ る。薬物のこのような性質の違いに伴い, 結合・解離の 時定数や膜への親和性が大きく変化するものと考えられ る。

\section{8 薬物の膜への結合の効率}

6 で示したように, FBPAの $k_{\mathrm{FB}}$ と $k_{\mathrm{BF}}$ は, 脂質の濃 度に依存して変化した。そこで, 脂質濃度を一定とした ときの結合・解離定数がどのように変化するかを検討し た。平衡状態では速度定数は $k_{\mathrm{FB}} f_{\mathrm{F}}=k_{\mathrm{BF}} f_{\mathrm{B}}$ を満足する。 したがって，脂質の濃度 $c_{\mathrm{EPC}}$ に対して

$$
\frac{k_{\mathrm{FB}} f_{\mathrm{F}}}{c_{\mathrm{EPC}}}=\frac{k_{\mathrm{FB}}\left(1-f_{\mathrm{B}}\right)}{c_{\mathrm{EPC}}}=\frac{k_{\mathrm{BF}} f_{\mathrm{B}}}{c_{\mathrm{EPC}}}=\text { const. }
$$

のようになる。 $\frac{k_{\mathrm{FB}}\left(1-f_{\mathrm{B}}\right)}{c_{\mathrm{EPC}}}$ は, Fig. 9 に示すように, い ずれの $c_{\mathrm{EPC}}$ においても $(4 \pm 2) \times 10^{4} \mathrm{~s}^{-1} \mathrm{M}^{-1}$ の範囲内に あり，概ね $c_{\mathrm{EPC}}$ に依存しないことがわかる。これより FBPAの膜への結合を解離の速度の脂質 1 分子あたり の值は， $c_{\mathrm{EPC}}$ が0〜 $3 \mathrm{mM}$ の範囲でほぼ一定となる ${ }^{10) 。 ~}$

薬物は膜の表面に到達しても, すべてが膜内に取り込 まれるとは限らない。膜表面にアクセスした薬物がどの 程度効率的に膜のなかに取り込まれるかを明らかにする ことができれば，ドラッグデザインなどの際に有効であ ると考えられる。そこで，筆者らは，5FUと FBPAに ついて, バルクから膜に取り达まれる際の効率を以下の ような方法で定量化した。まず最初に，バルクから膜表 面に到達するのに要する時間 $t_{\mathrm{R}}$ と膜に結合するのに要

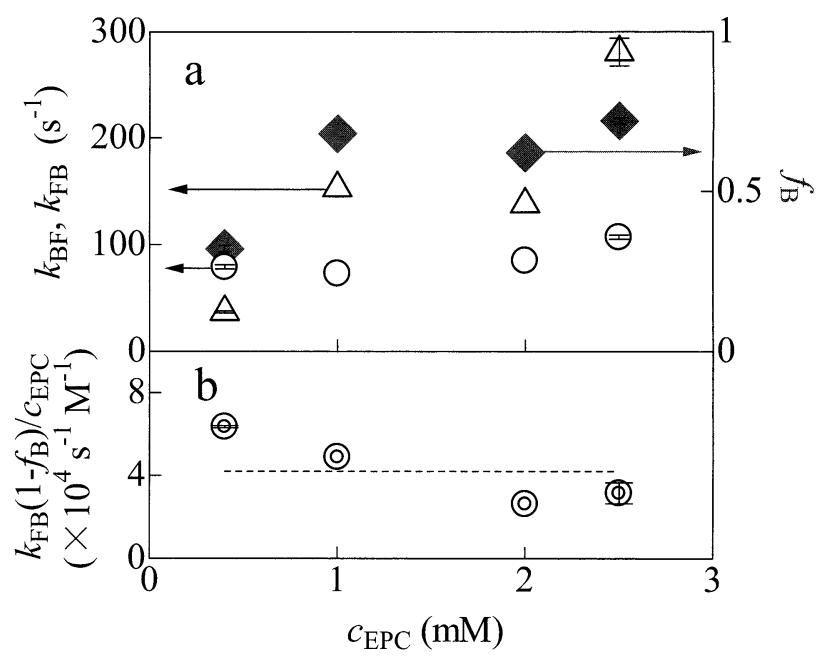

Fig. 9 Lipid concentration dependences of (a) the rate constants of FBPA binding $k_{\mathrm{FB}}$ (triangles) and dissociation $k_{\mathrm{BF}}$ (circles), the bound fraction $f_{\mathrm{B}}$ (diamonds, right axis), and (b) the values of $\frac{k_{\mathrm{FB}}\left(1-f_{\mathrm{B}}\right)}{c_{\mathrm{EPC}}}$ in eq. (6). 


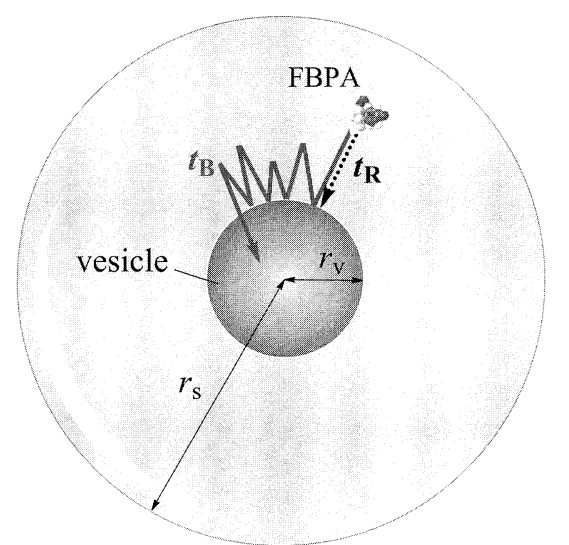

Fig. 10 Model for evaluating the efficiency of FBPA binding. Here FBPA in the spherical system of radius $r_{\mathrm{s}}$ binds to the vesicle of radius $r_{\mathrm{v}}, t_{\mathrm{R}}$ is the mean time interval for FBPA to reach at first to the membrane surface and $t_{\mathrm{B}}$ is the interval for FBPA to bind to the membrane.

する時間 $t_{\mathrm{B}}$ との比から, 新たに動的な結合確率 $P=t_{\mathrm{R}} / t_{\mathrm{B}}$ を定義した。 $t_{\mathrm{R}}$ は以下の式（7）で示される拡散律速反 応の反応時間に対する理論式を用いて求めることができ る。いま, Fig. 10 のように, 系全体の半径が $r_{\mathrm{s}}$, ベシ クルの半径が $r_{\mathrm{v}}$ の球で表され，それらの中心が同一の 点となるような場合を考える。このとき, 薬物がバルク からベシクル表面に到達するのに要する時間 $t_{\mathrm{R}}$ は,

$$
t_{\mathrm{R}}=\frac{r_{\mathrm{s}}^{2}}{D} \frac{\left(1-x^{2}\right)\left(5+6 x+3 x^{2}+x^{3}\right)}{15 x\left(1+x+x^{2}\right)}
$$

で表される ${ }^{10)}$ 。ここで $x=r_{\mathrm{v}} / r_{\mathrm{s}}$ であり，Dはベシクル の中心から見た時の薬物の相対的な拡散係数である。4 でみたように，膜に結合した薬物やベシクル自体の拡散 係数は, free の薬物に比べて約 2 桁程度小さいことから, ここでは $D$ として free の薬物の拡散係数 $D_{\mathrm{F}}$ を用いた。

Table 1 にFU およびFBPA の膜に対する結合確率 $P$ の值を示す。FBPAの場合, $P$ は $c_{\mathrm{EPC}}$ に依らず $0.04 \pm 0.01$

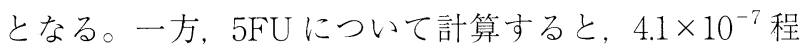
度であった。FBPAに比べて $5 \mathrm{FU}$ の值は1/100,000 程 度の小さな值となっており, 著しく膜の取り込み効率が 低下していることがわかる。FBPA に比べて $5 \mathrm{FU}$ が親 水的であることが強く影響していることによるものと考
えられる。

\section{9 おわりに}

筆者らは，膜の構造的なゆらぎゃ膜輸送などに関連し た分子の動きを理解するために，膜のなかの分子の運動 を NMR で直接観測する 2 種類の NMR 測定方法を開発 した。一つは，高分解能 NMR とパルス磁場勾配スピン エコー法を組み合わせたもの，もう一つは，脂質濃度を

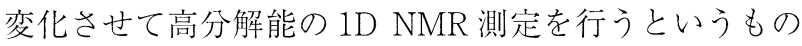
である。これらを親水的および疎水的な 2 種の薬物につ いて適切に使い分けることで，薬物の膜への結合，膜中 の拡散, および膜との結合・解離のキネティクスをin situで定量化することができた。系に摂動を与えること なくそのままの状態を捉えることが可能な NMR 測定 は，摇らぎをともなう膜へのドラッグデリバリー研究に 対して有力な手法である。今後，膜のなかの生理活性ぺ プチドや膜タンパク質の動態の解析，あるいは，生きた 細胞へのドラッグデリバリー研究など興味深い系への適 用が期待される。

本稿で紹介した筆者らの研究は, 科学研究費補助金・ 基盤研究（No. 20550027）㧍よび新学術領域研究「摇ら ぎが機能を決める生命分子の科学」(No. 21107527) か らの助成によって実施された。また，一部，資生堂女性 研究者サイエンスグラントからも助成をいただいた。こ こに深謝申し上げたい。

\section{文献}

1) E. Okamura \& M. Nakahara, Liquid Interfaces in Chemical, Biological, and Pharmaceutical Applications (A. G. Volkov edn), Marcel Dekker, New York, pp.775-805 (2001).

2) P. Stilbs, Prog. NMR Spectrosc., 19, 1-45 (1987).

3) E. Okamura, C. Wakai, N. Matubayasi, Y. Sugiura \& M. Nakahara, Phys. Rev. Lett., 93, 248101-1 4 (2004).

4) E. Okamura \& N. Yoshii, J. Chem. Phys., 129, 215102-1 $\sim 8$ (2008).

5) E. O. Stejskal \& J. E. Tanner, J. Chem. Phys., 42, 288-92 (1965).

6) H. C. Gaede \& K. Gawrisch, Biophys. J., 85, 1734-40

Table 1 Mean time intervals $t_{\mathrm{R}}$ and $t_{\mathrm{B}}$, and the dynamic binding probability $P$ of FBPA molecules. The values for $5 \mathrm{FU}$ calculated from the previous data ${ }^{8)}$ are also listed in the right column. All values are at $303 \mathrm{~K}$.

\begin{tabular}{cccccc}
\hline & \multicolumn{5}{c}{ FBPA } \\
\hline$c_{\mathrm{EPC}}(\mathrm{mM})$ & 0.4 & 1.0 & 2.0 & 2.5 & $5 \mathrm{FU}^{\mathrm{a}}$ \\
$t_{\mathrm{R}}(\mathrm{ms})$ & 0.92 & 0.34 & 0.15 & 0.12 & $1.8 \times 10^{-3}$ \\
$t_{\mathrm{B}}(\mathrm{ms})$ & 27 & 6.5 & 7.2 & 3.6 & $5.0 \times 10^{-3}$ \\
$P$ & $3.4 \times 10^{-2}$ & $5.2 \times 10^{-2}$ & $2.1 \times 10^{-2}$ & $3.3 \times 10^{-2}$ & $4.1 \times 10^{-7}$ \\
\hline
\end{tabular}

${ }^{\mathrm{a}} 5 \mathrm{FU}$ at $10 \mathrm{mM}$. 
(2003).

7) H. C. Gaede, W. M. Yau \& K. Gawrisch, J. Phys. Chem., B109, 13014-23 (2005).

8) N. Yoshii \& E. Okamura, Chem. Phys. Lett., 474,
357-61 (2009)

9) C. S. Johnson Jr., J. Magn. Reson., A102, 214-8 (1993).

10) N. Yoshii \& E. Okamura, submitted. 